\title{
Potential Primary Inoculum Sources of Bean pod mottle virus in Iowa
}

\author{
Rayda K. Krell and Larry P. Pedigo, Department of Entomology, John H. Hill, Department of Plant Pathology, \\ and Marlin E. Rice, Department of Entomology, Iowa State University, Ames 50011
}

\begin{abstract}
Krell, R. K., Pedigo, L. P., Hill, J. H., and Rice, M. E. 2003. Potential primary inoculum sources of Bean pod mottle virus in Iowa. Plant Dis. 87:1416-1422.

A survey of Bean pod mottle virus (BPMV) in Iowa counties was conducted and the virus was found throughout the state. A long-term monitoring study (1989 to 2002) of the main BPMV vector, the bean leaf beetle, Cerotoma trifurcata, indicated that, in 2002, populations reached the highest abundance recorded in 14 years. Three potential sources for an early season primary inoculum source were found: (i) soybean (Glycine max) seed, (ii) overwintered bean leaf beetles, and (iii) alternate BPMV host plants. Examination of 5,804 and 8,064 soybean seedlings of two cultivars yielded 0 and 3 seedlings, respectively, infected with BPMV. In a separate test, BPMV was detected in mottled and nonmottled soybean seed. Some mottled seed did not contain BPMV, indicating that soybean seed coat mottling is an unreliable indicator for presence of the virus in seed. Of 194 naturally overwintered bean leaf beetles, only 1 transmitted BPMV to soybean. BPMV was detected serologically only in 1 alternate host, Desmodium canadense, out of 23 naturally occurring plant species collected from the field. The three inoculum sources discovered in Iowa in this study could be important primary sources when vector populations are high and indicate starting points for future epidemiological investigations.
\end{abstract}

A recent Bean pod mottle virus (BPMV) epidemic in north-central U.S. soybean (Glycine $\max (\mathrm{L})).(13)$ has created new concerns for growers. BPMV causes yield reductions and seed coat discoloration and no resistance is known in conventional soybean cultivars (13). The primary vector for BPMV transmission to soybean is the bean leaf beetle, Cerotoma trifurcata (Forster), which is the main agent of virus spread during the growing season (13). BPMV first was identified in South Carolina in 1947 (56). As early as 1966, it was identified from field-collected soybean in Iowa (37), but the virus was not considered common until the late 1990s, when growers reported an increased incidence of discolored soybean seed (55).

Despite the long history of BPMV in the United States, its epidemiology is poorly understood and work in this area has been conducted primarily in southern states. In the north-central United States, differences in climate, soybean cultivars, and man-

Corresponding author: R. K. Krell

E-mail: rayda.krell@ucr.edu

Current address for R. K. Krell: Department of Entomology, University of California, Riverside 92521.

This journal paper of the Iowa Agriculture and Home Economics Experiment Station, Ames, Iowa, Project No. 2428, was supported by Hatch Act and State of Iowa funds.

Accepted for publication 16 June 2003.

Publication no. D-2003-1002-02R

(C) 2003 The American Phytopathological Society agement practices could all contribute to differences in BPMV epidemiology. Because of the epidemic of BPMV in the north-central United States, research that can contribute to understanding BPMV epidemiology is needed.

One step in understanding epidemiology is to identify primary sources of inoculum. A primary inoculum source is one that causes the original infection at the beginning of the disease cycle (1). The success of plant-virus management relies on identification of primary sources of virus inoculum and an understanding of virus ecology (6). There are at least three potential BPMV primary inoculum sources for soybean: infected seed, overwintered insect vectors, and perennial host plants. Two studies have documented low levels $(<1 \%)$ of BPMV seed transmission $(28,38)$. In other studies, no seed transmission of BPMV was detected $(41,43)$.

Overwintered bean leaf beetles may serve as a reservoir for BPMV during winter, but transmission by these beetles is reportedly low ( 0 to $17 \% ; 2,33,54)$. In one study from Arkansas, $13.5 \%$ of bean leaf beetles collected from overwintering sites transmitted BPMV, and $8.3 \%$ of beetles collected from an alfalfa (Medicago sativa L.) field on 1 April transmitted the virus (33). A limitation to these studies is that beetles were artificially disturbed during overwintering; therefore, transmission detected may not reflect natural post-overwintering transmission. Additionally, identifying BPMV transmission from beetles collected from alfalfa in April suggests that transmissible virus may survive in beetles during winter; however, these tests did not exclude the possibility of beetle virus acquisition from a BPMV-infected alternate host plant after overwintering. In contrast, Anjos (2) demonstrated that naturally overwintered beetles did not transmit BPMV, but beetle regurgitant tested positive serologically. For BPMV-carrying beetles that were artificially overwintered at $4{ }^{\circ} \mathrm{C}, 6.6 \%$ transmitted the virus to soybean and $0.02 \%$ collected from alfalfa transmitted BPMV (2). No study has reported BPMV overwintering in bean leaf beetles in the north-central United States. Other chrysomelid vectors for BPMV are known (13), but none have been tested as overwintering reservoirs for BPMV.

Horn et al. (20) and Stace-Smith (45) suggested that the principle source of primary inoculum for BPMV is infected perennial host plants. BPMV can infect several plant species in the family Fabaceae (13), but none have been identified conclusively as principle primary sources of inoculum. Basic information is needed on the importance of these hosts in virus ecology under natural field conditions, and their relationship with vectors, before their importance as principle primary inoculum sources can be determined.

The objective of this study was to identify and assess potential sources of primary inoculum for BPMV in Iowa, the top producer of soybean in the United States (34). Results from this study are important for understanding the recent BPMV epidemic throughout the north-central United States and may assist in development of virus management tactics.

\section{MATERIALS AND METHODS}

Virus detection. Immunological assays. All plant samples for immunological assays were extracted in phosphate-buffered saline (PBS) (0.05 M sodium phosphate, $\mathrm{pH} 7.0$, with $0.15 \mathrm{M} \mathrm{NaCl}$ ) using a sap extractor (Ravenel Specialties Corp., Seneca, SC).

The biotin-avidin double-antibody sandwich enzyme-linked immunosorbent assay (ELISA) used was similar to that for Soybean mosaic virus (SMV; 46), except that BPMV polyclonal antibodies prepared to the I-JH1 BPMV isolate (14) were used to coat plates and biotinylated polyclonal BPMV antibodies were used for detection. Samples were considered positive if the absorbance value of duplicate wells was greater than the mean plus twice the standard deviation of the negative control (sap from noninoculated soybean leaves). For assays of virus in soybean seed, seed were 
extracted as described by Bryant et al. (7) and tested by ELISA for SMV and BPMV. Tests for SMV were performed because it can cause seed coat mottling similar to that caused by BPMV (18). Methods for SMV assay by ELISA were previously described by Steinlage et al. (46).

Plant species other than soybean were tested by ELISA for BPMV and tested by dot blot assay (17) because it was thought this method would eliminate the possibility of nonspecific binding to the primary antibody. Samples $(100 \mu \mathrm{l})$, prepared as for ELISA, were spotted on a supported nitrocellulose membrane $(0.45-\mu \mathrm{m}$ pore size; Schleicher and Schuell, Keene, NH) secured to a Bio-Dot microfiltration apparatus (Bio-Rad, Hercules, CA). The membrane was blocked with $5 \%$ nonfat dried milk in PBS with $0.05 \%$ Tween 20 (PBST). After blocking, primary antibody was added at $1.0 \mu \mathrm{g} / \mathrm{ml}$. After incubation with goat anti-rabbit immunoglobulin Galkaline phosphatase conjugate $(1: 10,000$; (Sigma-Aldrich, St. Louis), the membrane was incubated in NBT/BCIP (nitroblue tetrazolium / 5-bromo-4-chloro-3-indolylphosphate) according to the manufacturer's instructions (Promega Corp., Madison, WI). Immunoreagents were in PBST and incubation times were $60 \mathrm{~min}$ except for the final reaction, which was approximately $20 \mathrm{~min}$.

Some samples that tested positive for BPMV by ELISA or dot blot were further tested by Western blot following a procedure similar to that of Anjos et al. (3). Previous work has suggested that some forage legumes can yield unreliable results in some immunological assays without rigorous refinement of protocols specific to each plant species (30). Consequently, Western blotting was used as a definitive method for determining BPMV-positive samples from plant species other than soybean.

The samples were concentrated before testing by placing $200 \mu \mathrm{l}$ of each sample in a 1.5-ml microcentrifuge tube with dialysis membrane $(12,000$ to $14,000 \mathrm{MW})$ covering the lid (35). The sample was inverted in a test tube and centrifuged at 1,570 $\times g$ (International Equipment Co., Needham, MA) until the sample volume had been decreased to approximately $50 \mu \mathrm{l}$. A $20-\mu \mathrm{l}$ sample aliquot was mixed with $40 \mu \mathrm{l}$ of Laemmli buffer (26) (0.5 M Tris, $\mathrm{pH} 6.8$, $19 \%$ glycerol, $3.8 \%$ sodium dodecyl sulfate [SDS], and 9.5\% 2-mercaptoethanol), heated at $95^{\circ} \mathrm{C}$ for $4 \mathrm{~min}$, and $35 \mu \mathrm{l}$ was loaded in each well of a $12 \%$ SDSpolyacrylamide gel. Samples were electrophoresed at $200 \mathrm{~V}$ for approximately 45 min. BPMV-infected soybean sap was used as a positive control, and sap from noninoculated soybean served as a negative control. Proteins were transferred overnight to a supported nitrocellulose membrane (Schleicher and Schuell) by using a Transblot Cell (Bio-Rad, Richmond, CA) at $30 \mathrm{~V}$ in Tris/192 $\mathrm{mM}$ glycine buffer, $\mathrm{pH}$ 8.3 , containing $20 \%$ methanol (48). After transfer, the nitrocellulose membrane was blocked in 5\% nonfat dried milk in PBST. Subsequent procedures were as described for dot blots except that the primary and secondary antibodies were used at 30.0 $\mu \mathrm{g} / \mathrm{ml}$ and $1: 1500$, respectively, and incubation times were increased to $2.5 \mathrm{~h}$.

Biological assay. Transmissibility of BPMV was confirmed by local lesion assay, performed on Pinto bean (Phaseolus vulgaris L.; 56), for soybean tissue samples on which overwintered bean leaf beetles had fed.

BPMV distribution and bean leaf beetle abundance. The distribution of BPMV in Iowa and bean leaf beetle abundance by year were evaluated. The distribution of BPMV was evaluated in August and September 2000. In 84 of Iowa's 99 counties, at least 20 live bean leaf beetles per county at one to four locations were collected from farmers' fields using a sweep-net (38$\mathrm{cm}$ ) and mailed to the laboratory at Iowa State University, Ames. Beetles were frozen immediately $\left(-20^{\circ} \mathrm{C}\right)$ and later macerated individually in 1.5-ml microcentrifuge tubes with $1 \mathrm{ml}$ of PBS. Macerated samples were frozen until analysis by ELISA. Beetles that had fed on BPMV-infected soybean yielded ELISA absorbance values (0.34 to 0.53) similar to those of BPMVinfected soybean sap (0.50 to 0.57). Because it was difficult to obtain virus-free beetles, beetles that yielded ELISA absorbance values in the range of 0.01 to 0.07 were considered negative for BPMV. In subsequent tests of bean leaf beetles, sap from infected and uninfected soybean were used as controls.

Bean leaf beetle second-generation population abundance was monitored at the Iowa State University Johnson Farm because it is the most common BPMV vector in Iowa. Data from 1989 to 1998 were summarized by Lam et al. (27) and were combined with continued monitoring data from 1999 to 2002. From 1999 to 2002, methods were similar to Lam et al. (27), except only three fields were sampled. For each year, means were calculated from all three plots for each week of sampling. A mean of the number of bean leaf beetles collected in 50 sweeps was calculated for the entire second-generation population by year from the mean of the 3 or 4 weeks that the second-generation population was sampled. Differences between mean second-generation bean leaf beetle populations were compared using analysis of variance (40).

Seed-coat mottling and seed transmission. Soybean seed were harvested from two soybean cultivars, A and B, from a grower's field in Correctionville, IA. Soybean leaf tissue from this area had been shown to be infected with BPMV and bean leaf beetles from this area were found to transmit BPMV to soybean in greenhouse tests. Three 100-seed samples of these soybean cultivars were visually evaluated for seed coat mottling. Any seed with seed coat discoloration was considered mottled. After counting, the three samples of each cultivar were combined, and one 100-seed sample from each cultivar was tested for SMV and BPMV by ELISA. Seed of an additional 100-seed sample from each cultivar were individually assessed for presence of seed coat mottling and placed in microcentrifuge tubes. Each seed was macerated in $1 \mathrm{ml}$ of PBS and tested for BPMV by ELISA.

To examine potential seed transmission, 5,804 and 8,064 seed of the two cultivars, $\mathrm{A}$ and $\mathrm{B}$, respectively, were planted in December through February 2000 in a greenhouse. Plants, grown under supplemental light (14 h light, $10 \mathrm{~h}$ dark), were evaluated at the V2 growth stage (10). Sap from leaves of 226 plants of cultivar A and 274 plants of cultivar B that showed viruslike symptoms (e.g., stunting, leaf mottling, or rugosity) were extracted. Samples were stored frozen at $-20^{\circ} \mathrm{C}$ until analysis by ELISA. Seed from BPMV- and SMVindexed greenhouse grown soybean were used as negative controls.

Transmission of BPMV by overwintered bean leaf beetles. Leaf litter was collected in February and March 2000 from wooded areas close to soybean fields in Correctionville and Ames, IA. In March 2001, leaf litter was collected from the areas near Ames only. Following collection, leaf litter was placed in $5.3-\mathrm{m}^{3}$ screen cages (1- by 1-mm mesh) located outdoors in Ames, IA. During April through June, cages were monitored daily for beetle emergence from leaf litter. As beetles naturally emerged, they were removed and placed on V1- to V3-stage soybean plants in a greenhouse at a density of one beetle per plant. Assay seedlings were grown from seed harvested from virus-free Williams 82 soybean that had been grown in a greenhouse. In 2000 and 2001, 152 and 42 beetles, respectively, were collected. Cylindrical, clear plastic cages ( 62.2 by 47.5 $\mathrm{cm})$ covered on one end with white elastic hose (95\% nylon, 5\% spandex) were placed over each plant in a pot. After an inoculation access time of 3 weeks, each beetle was macerated in $1 \mathrm{ml}$ of PBS and frozen until testing by ELISA. All plants on which beetle feeding occurred were grown for an additional 3 weeks, after which three trifoliolate leaves on which beetles had not fed were harvested from each plant and extracted individually in PBS for ELISA. Final confirmation of ELISA-positive samples was determined by Western blot and local lesion assay.

Potential alternate BPMV host plants. Plants representing 22 fabaceous and 1 solanaceous species were collected from sites with high BPMV incidence in central and northwestern Iowa, including forage trials at Iowa State University research 
farms, prairies, and roadside areas. Some plant species evaluated had previously been reported as hosts for BPMV, but not from naturally occurring plants in Iowa. A single sample comprised a combined group of approximately one to five individual plants. Samples, collected on various dates from April through September 2000 and 2001, were extracted in PBS and tested by ELISA and dot blot assay. Any ELISA- or dot blot-positive sample was further tested by Western blot.

\section{RESULTS AND DISCUSSION}

BPMV distribution and bean leaf beetle abundance. Previous work showed that presence of BPMV in bean leaf beetles reliably predicted virus field incidence (12); therefore, presence of BPMV in a county was determined by identification of at least one serologically positive beetle sample. Beetles examined from all 84 counties were positive for BPMV (ELISA values 0.18 to 0.65 ), indicating that the virus was distributed throughout the state (Fig. 1). The percentage of tested counties in which beetles were positive for BPMV $(100 \%)$ was similar to percentages determined from surveys conducted in Mississippi $(91 \%$; 36), North Carolina (90\%; 39), and Kentucky (100\%; 12). However, in this study, more counties were surveyed than in other states reporting BPMV distribution, and results showed that BPMV was present in all soybean-growing regions of Iowa.

From 1997 to 2002, the second-generation bean leaf beetle population increased almost eightfold and the population in 2002 reached the highest abundance recorded in 14 years (Fig. 2). It is likely that the perceived increase in BPMV incidence in Iowa is related to the increase in bean leaf beetle abundance.

Seed-coat mottling and seed transmission. Of seed tested, 65 and $87 \%$ were identified as mottled from cultivars A and B, respectively. By ELISA, combined 100seed samples were positive for BPMV and negative for SMV. Both viruses are known to cause seed coat mottling $(5,45)$, and analysis of 100 individual seed of both cultivars showed that mottled seed could be either positive or negative for BPMV (Table 1). Additionally, some nonmottled seed were positive for BPMV (Table 1), indicating that seed coat mottling is an unreliable indicator for virus presence in a single seed. Because the seed lots tested negative for SMV, it is less likely that this virus was the cause of mottled seed.

In this report, seed transmission of BPMV was not detected from cultivar A and was detected in three $(0.037 \%)$ seedlings of cultivar B. This low level of BPMV seed transmission agrees with those reported in previous studies conducted almost 20 years earlier $(28,38)$. The level of seed transmission reported here is conservative because only symptomatic seed-

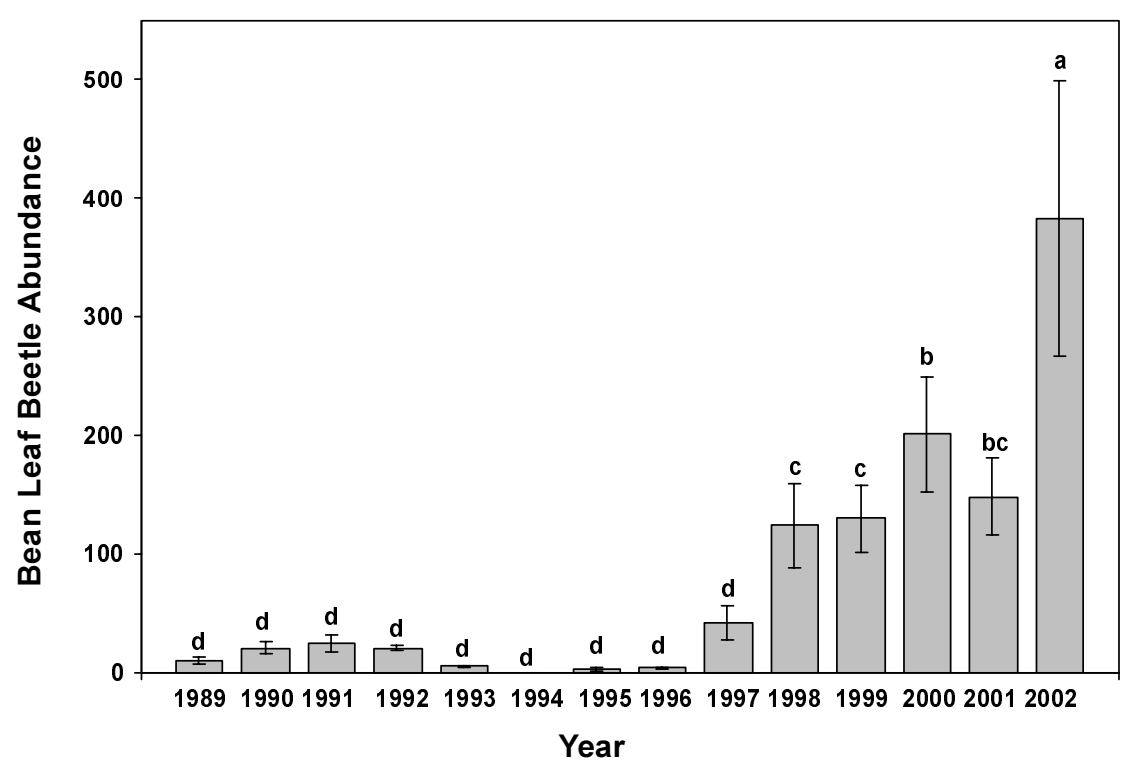

Fig. 2. Bean leaf beetle mean $( \pm \mathrm{SE})$ second-generation population abundance at Iowa State University Johnson Farm, Ames. Means not followed by the same letter are significantly different $(P$ $<0.05)$.

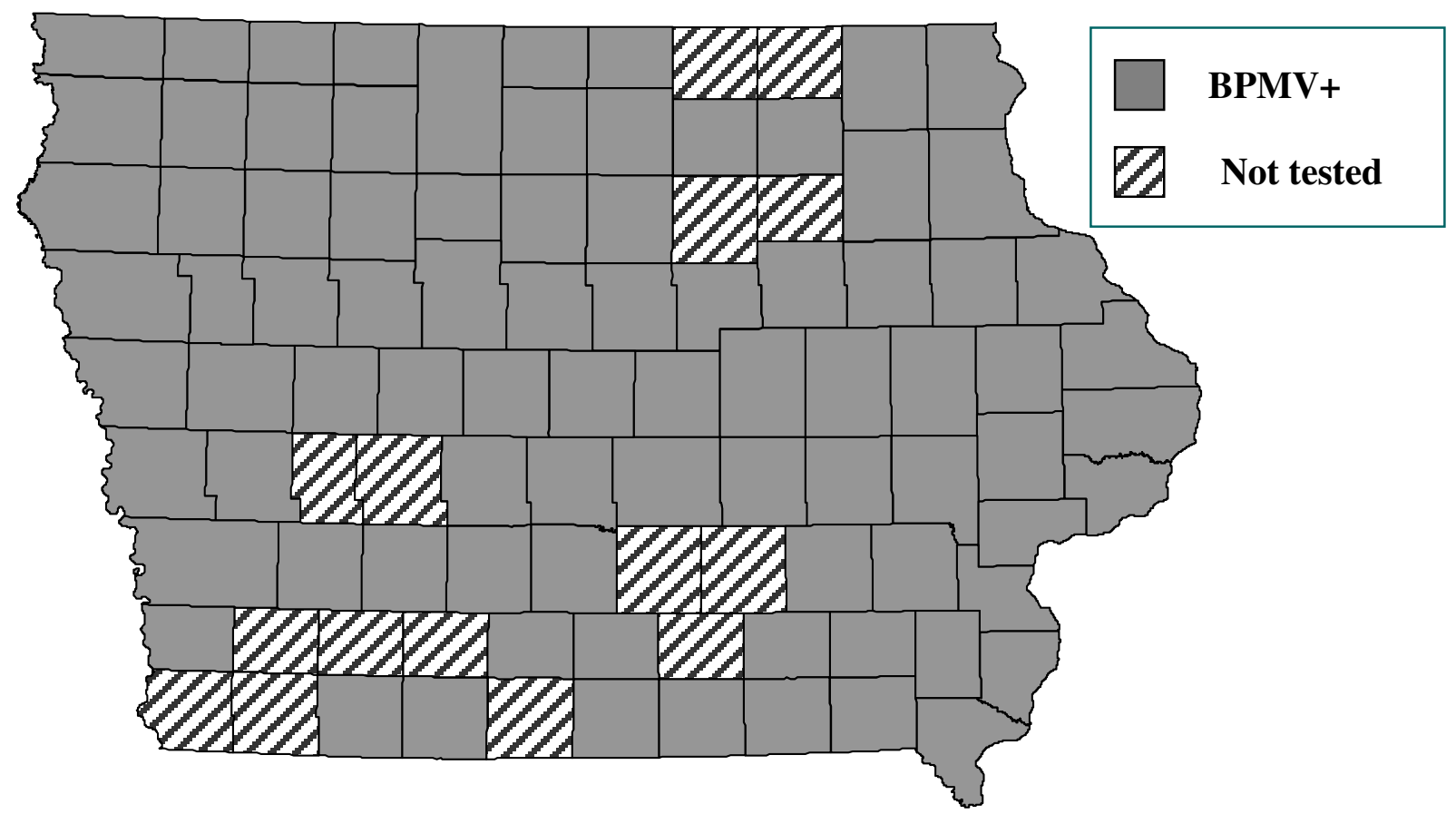

Fig. 1. Iowa counties in which Bean pod mottle virus (BPMV) was identified from bean leaf beetles by enzyme-linked immunosorbent assay. 
lings were analyzed. If some BPMVinfected seedlings were symptomless hosts, the transmission level of seed transmission could be higher. It is possible that low BPMV seed transmission is an intrinsic BPMV trait because all three studies used different soybean cultivars that were from different states, and the tests were performed in different years. However, even at this low level, it may be sufficiently high for seed to serve as an important primary inoculum source when vector populations are high. The low levels of seed transmission reported (0.012 to $0.037 \%)$ probably would not be sufficient to cause economic losses from BPMV because $40 \%$ infected plants has been calculated as the threshold required to result in economic loss (21). Ross (38) suggested that a high vector population with a small inoculum source could be enough for beetles to spread BPMV throughout a field early in plant development, thus maximizing yield and quality losses.

Few studies have investigated early-season field levels of BPMV. In a separate study to evaluate insecticide application as a management tactic for reducing BPMV vectors and BPMV incidence, VC stage soybeans were assayed for BPMV by ELISA prior to insecticide treatment (25). In that study, BPMV field incidence at the VC soybean stage was $54 \%(n=94)$ and $56 \%(n=80)$ in two different fields. This relatively high field incidence suggests that early-season inoculum sources could be an important primary source for future disease spread. The early-season levels detected could be the result of BPMV seed transmission and subsequent secondary spread by bean leaf beetles. Alternatively, viruliferous beetles from other primary sources identified (overwintering in insect or alternate host plants) may have contributed to secondary spread to emergent seedlings. Epidemiological work to quantify the relationship between seed transmission and vector populations is needed to confirm whether the low levels detected in this and other studies are important.

Transmission of BPMV by overwintered bean leaf beetles. Of 64 overwintered beetles, 1 (1.6\%) from Correctionville transmitted BPMV to an assay soybean plant in 2000 (Table 2), confirming that overwintered bean leaf beetle

Table 1. Presence of Bean pod mottle virus (BPMV) in 100 individual soybean seed of two soybean cultivars ${ }^{\mathrm{a}}$

\begin{tabular}{lcrllll}
\hline & \multicolumn{2}{c}{$\begin{array}{c}\text { Mottled } \\
\text { seed }\end{array}$} & & \multicolumn{2}{c}{$\begin{array}{c}\text { Nonmottled } \\
\text { seed }\end{array}$} \\
\cline { 2 - 3 } \cline { 6 - 6 } Cultivar & + & - & & + & - \\
\hline A & 47 & 18 & & 31 & 4 \\
B & 79 & 8 & & 13 & 0 \\
\hline
\end{tabular}

${ }^{a}$ Individual seed tested positive (+) or negative $(-)$ for BPMV by enzyme-linked immunosorbent assay. transmission to soybean can occur. The presence of BPMV coat protein in the soybean sample was confirmed by ELISA and Western blot (Fig. 3A), and biologically by local lesion assay (data not shown). No beetles transmitted BPMV in 2001. Despite the low percentage of transmission to soybean, several beetles were positive as carriers of BPMV (ELISA values, 0.11 to 0.59 ) when macerated and tested at the end of the study (Table 2). Of the beetles tested, $24 \%$ in 2000 and $57 \%$ in 2001 were BPMV-positive from Ames, and $27 \%$ of the beetles from Correctionville were BPMV-positive in 2000.

The beetle transmission rate is lower than that reported by Walters et al. (54) and Mueller and Haddox (33). The Walters et al. (54) report did not include the method used to assay plants for BPMV or the soybean stage used to test transmission; therefore, it is not possible to evaluate the significance of the results to what might occur in the field. It also is possible that colder winters in Iowa compared with Arkansas, where the Walters et al. (54) study was performed, could cause differences in transmission after overwintering. A strong positive relationship has been well documented between BPMV inoculation at early soybean stages and greater yield loss (19). Because a high percentage of infected plants have been found in the field as early as VC, (25) future studies examining BPMV inoculum sources might consider examining BPMV transmission by overwintered beetles by using VE or VC (10) soybean developmental stages.

The discrepancy between the low rate of beetle BPMV transmission and relatively high number of beetles that tested positive for BPMV may be because of virus aging (29). Proteolysis of the small coat-protein subunit that occurs at the $\mathrm{C}$ terminus with aging may make the virus nontransmissible by beetles (2). Another possible explanation is that the conditions for successful BPMV transmission after beetle overwintering may be highly specific, such that only a small percentage of beetles would experience those conditions during overwintering. Overwintered beetles that transmit BPMV may need to acquire the virus during overwintering by feeding on shoots or roots of infected host plants below the leaf litter (54). Overwintering beetles have been found with food in the gut (4), and this condition could enable the virus to remain intact longer in plant tissue that is not entirely digested. Another factor that may affect overwintering of transmissible virus in beetles is that beetles feed on alternate host plants after soybean senescence and before overwintering (44). Several bean leaf beetle host plants are also hosts for BPMV (Table 3). Perhaps preoverwintering food choice affects BPMV overwintering in beetles if host species differentially affects virus aging and, hence, potential for transmission. Transmission of BPMV by overwintered beetles may be further complicated because there are several virus strains (14) and, presumably, beetle biotypes that may interact differently under various overwintering conditions. Although the mechanism of BPMV overwintering in beetles remains unresolved, its apparent occurrence at low levels in the beetle population provides an additional explanation for detection of infected plants at the VC growth stage in the field (25).

Alternate BPMV host plants. BPMV's natural host range includes just four plant species, Desmodium canadense (L.), D. paniculatum (L.), Glycine $\max$ (L.), and Phaseolus vulgaris (L.) (Table 3). Even though BPMV can infect at least 10 additional species mechanically, only natural BPMV hosts that are also hosts for the bean leaf beetle are candidate primary inoculum sources. In our study, we attempted to identify other plants endemic to Iowa that could be added to the list of natural hosts. Of the 23 plant species we examined, 16 tested positive for BPMV by ELISA, and 12 of these species were positive by dot blot assay. However, only one D. canadense sample revealed protein bands that occurred coincidentally with those from soybean tissue infected with BPMV in Western blots (Fig. 3B). Therefore, we conclude that $D$. canadense is the only natural alternate host species for BPMV of those tested. This BPMV-positive sample was collected from northwestern Iowa, where this plant is common (9), on 11 June 2000. Finding a BPMV-infected D. canadense plant, a perennial species, on this early date suggested it could serve as a

Table 2. Bean pod mottle virus (BPMV) transmission to soybean seedlings by overwintered bean leaf beetles collected in Iowa

\begin{tabular}{lcccc}
\hline Year & Location collected & Beetles tested $^{\mathbf{a}}$ & Beetles positive $^{\mathbf{b}}$ & Plants positive $^{\mathbf{c}}$ \\
\hline 2000 & Ames & 88 & $20 / 82^{\mathrm{d}}$ & 0 \\
2000 & Correctionville & 64 & $16 / 59^{\mathrm{e}}$ & $1^{\mathrm{f}}$ \\
2001 & Ames & 42 & $20 / 35^{\mathrm{g}}$ & 0 \\
\hline
\end{tabular}

a Total beetles tested for BPMV transmission.

b Total beetles positive for BPMV by enzyme-linked immunosorbent assay.

${ }^{c}$ Total soybean plants positive for BPMV by Western blot.

${ }^{\mathrm{d}}$ Six beetles could not be tested because they could not be found in cages.

${ }^{\mathrm{e}}$ Five beetles could not be tested because they could not be found in cages.

${ }^{\mathrm{f}}$ Local lesion assay and macerated bean leaf beetle from this plant were also positive.

g Seven beetles could not be tested because they could not be found in cages. 
A

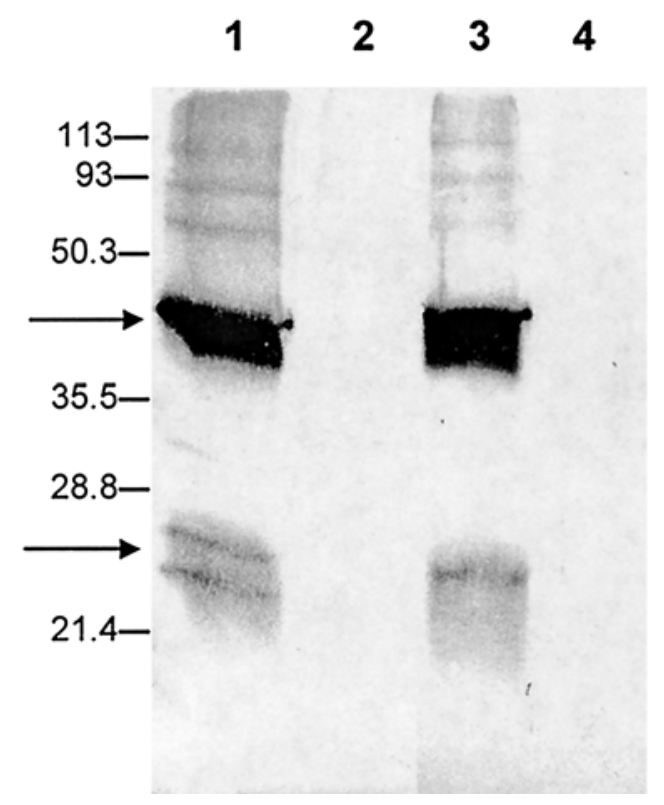

B

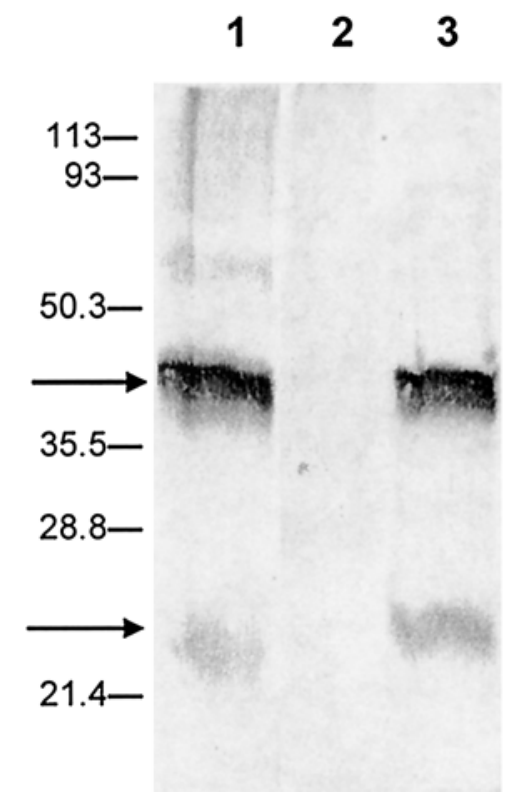

Fig. 3. Detection of Bean pod mottle virus (BPMV) by Western blotting. A, Overwintered bean leaf beetle transmission of BPMV. Samples from soybean leaf tissue mechanically inoculated with BPMV (lane 1), noninoculated soybean leaf tissue (lane 2), and leaf tissue from soybean plants used for a 3-week inoculation access period by individual overwintered bean leaf beetles (lanes 3 and 4). B, Detection of BPMV in naturally occurring host plants. Samples from soybean leaf tissue mechanically inoculated with BPMV (lane 1) noninoculated soybean leaf tissue, (lane 2), and leaf tissue from field-collected Desmodium canadense (lane 3). Molecular weights of markers are shown to the left of each panel. Arrows to the left of each panel designate BPMV capsid proteins. The two bands indicated by the bottom arrow in A represent the slow- and fast-migrating forms of the BPMV small coat protein, respectively (29).

Table 3. Known hosts of Bean pod mottle virus (BPMV) and the bean leaf beetle in North America ${ }^{\mathrm{a}}$

\begin{tabular}{ll}
\hline Identification, host $\mathbf{b}^{\mathbf{b}}$ & Bean leaf beetle host plant? \\
\hline Natural occurrence & \\
Desmodium canadense (L.) (20) & Yes (this report) \\
D. paniculatum (L.) (32) & Yes (53) \\
Glycine max (L.) (52) & Yes (24) \\
Phaseolus vulgaris L. (56) & Yes (50) \\
Mechanical inoculation & \\
Glycine spp. (42) & Yes (16) \\
Lespedeza cuneata G. (43) & Not reported \\
L. stipulacea Maxim. (43) & Not reported \\
L. striata L. (43) & Yes (24) \\
Phaseolus lunatus L. (47) & Yes (8) \\
Pisum sativum L. (15) & Not reported \\
Stizolobium deeringianum Bort. (43) & Not reported \\
Trifolium incarnatum L. (43) & Yes (24) \\
Vigna sinensis (L.) (43) & Yes (50) \\
V. unguiculata (L.) (15) & Yes (22) \\
\hline
\end{tabular}

a Reference in parentheses.

$\mathrm{b}$ Method of BPMV host plant identification and BPMV host plants.

primary inoculum source for BPMV. Also, bean leaf beetles were observed feeding on this species on 16 May 2000 before soybean seedlings had emerged, indicating it is a potential host plant before movement to soybeans. Although D. canadense has been identified as a natural host of BPMV in Louisiana (20), this is the first report of natural BPMV-infected $D$. canadense from the north-central United States. There are no reports of BPMV transmission from $D$. canadense to soybean by bean leaf beetles; however, transmission from $D$. paniculatum (L.) to soybean was shown (53). Desmodium paniculatum is the only BPMV alternate host for which transmission by further investigation into their contribution to BPMV epidemiology.

Most plants tested had not been previously reported as BPMV hosts; however, two hosts shown to be susceptible to BPMV by mechanical (noninsect) inoculation, Lespedeza striata L. and Trifolium incarnatum L. (Table 3), were not confirmed as natural hosts (Table 4). It is possible that too few plants of these species were sampled. Alternatively, it is possible that some hosts susceptible to mechanical inoculation may not become infected naturally. Susceptibility of most BPMV host plants has been determined by mechanical inoculation only (Table 3). Although not shown for BPMV, determination of a BPMV host species based on mechanical inoculation may be unimportant in virus ecology, depending on vector preference (Table 3), phenology, or inhibition of transmission. Gergerich and Scott (11) speculated that beetle regurgitant functions by affecting the host or the interaction of the virus with the host. Beetle regurgitant can be a selective determinant of beetle virus transmission, but there is no evidence for direct inactivation by regurgitant of nonbeetle-transmissible viruses (11). Identification of host plants by mechanical BPMV inoculation can be used to identify potential naturally occurring host plants, but these data should be followed by field identification of these plants as hosts before conclusions are made about their roles in virus ecology. Efforts are in progress to assess additional host plant species from the field. 
Table 4. Results of testing for naturally occurring Bean pod mottle virus (BPMV) host plants

\begin{tabular}{|c|c|c|}
\hline Host plant & Total no. of samples & Positive by Western blot \\
\hline Amorpha canescens Pursh & 1 & - \\
\hline Astragalus cicer $\mathrm{L}$. & 1 & - \\
\hline Baptisia lactea Raf. & 1 & - \\
\hline Caragana arborescens Lam. & 1 & - \\
\hline Cladrastis lutea Michx. & 2 & - \\
\hline Coronilla varia $\mathrm{L}$. & 1 & - \\
\hline Dalea purpurea Vent. & 1 & - \\
\hline Desmodium canadense (L.) & 2 & + \\
\hline Desmodium spp. & 3 & - \\
\hline Gleditsia triacanthos L. & 1 & - \\
\hline Lespedeza capitata Michx. & 3 & - \\
\hline L. striata $\mathrm{L}$. & 1 & - \\
\hline Lotus corniculatus L. & 6 & - \\
\hline Medicago sativa $\mathrm{L}$. & 26 & - \\
\hline Melilotus alba Med. & 22 & - \\
\hline M. officinalis (L.) & 1 & - \\
\hline Psoralea argophylla Pursch & 1 & - \\
\hline Robinia pseudoacacia L. & 2 & - \\
\hline Solanum carolinense $\mathrm{L}^{\mathrm{a}}$ & 1 & - \\
\hline Trifolium ambiguum L. & 1 & - \\
\hline T. hybridum L. & 1 & - \\
\hline T. incarnatum L. & 1 & - \\
\hline T. pratense L. & 31 & - \\
\hline Vicia villosa Roth & 1 & - \\
\hline
\end{tabular}

${ }^{\mathrm{a}}$ Family = Solanaceae, all others are Fabaceae .

This study documents three potential primary inoculum sources for BPMV in Iowa and provides a foundation for future epidemiological studies. No single inoculum source identified in this study occurred at a high enough level to implicate it as a principle source. Although the percentage of beetles transmitting BPMV after overwintering was low, the total beetles transmitting BPMV could be high when beetle populations are large and BPMV inoculum was abundant in the previous season. BPMV seed transmission may be more important than previously thought. It is possible that the combined effect of multiple inoculum sources contributes to the high level of early-season infection that has been documented, and it may not be possible to break the disease cycle by targeting a single inoculum source. The most promising management tactics presently are those that focus on inhibiting the most important mechanism for virus spread, the bean leaf beetle (13); however, soybean resistance to BPMV will provide the most sustainable long-term solution.

\section{ACKNOWLEDGMENTS}

We thank the Iowa Soybean Promotion Board and the North Central Soybean Research Program for funding this study, W. F. Lam and J. D. Bradshaw for helping to compile data on bean leaf beetle population abundance, R. O. Pope for expert advice on field sites for plant collection and plant identification, A. L. Eggenberger and M. R. Hajimorad for assistance in refining methods for immunological assays and for suggestions on this manuscript, J. L. Todd for her editing expertise, and L. L. Domier for his careful review and thoughtful suggestions.

\section{LITERATURE CITED}

1. Agrios, G. N. 1996. Plant Pathology. Academic Press, San Diego, CA.

2. Anjos, J. R. 1991. Studies on the epidemiology and molecular biology of two soybean vi- ruses: soybean mosaic virus and bean pod mottle virus. Ph.D. diss., University of Kentucky, Lexington.

3. Anjos, J. R., Jarlfors, U., and Ghabrial, S. A. 1992. Soybean mosaic potyvirus enhances titer of two comoviruses in dually infected soybean plants. Phytopathology 82:10221027.

4. Boiteau, G., Bradley, J. R., Jr., and Van Duyn, J. W. 1979. Bean leaf beetle: some seasonal anatomical changes and dormancy. Ann. Entomol. Soc. Am. 72:303-307.

5. Bowers, G. R., Jr., and Goodman, R. M. 1979. Soybean mosaic virus: infection of soybean seed parts and seed transmission. Phytopathology 69:569-572.

6. Broadbent, L. 1969. Disease control through vector control. Pages 593-630 in: Viruses, Vectors, and Vegetation. K. Maramorosch, ed. Interscience Publishers, New York.

7. Bryant, G. R., Hill, J. H., Bailey, T. B., Tachibana, H., Durand, D. P., and Benner, H. I. 1982. Detection of soybean mosaic virus in seed by solid-phase radioimmunoassay. Plant Dis. 66:693-695.

8. Chittenden, F. H. 1897. The bean leaf beetle. U. S. Dep. Agric. Div. Entomol. Bull. No. 9:64-71.

9. Eilers, L. J., and Roosa, D. M. 1994. The Vascular Plants of Iowa: An Annotated Checklist and Natural History. University of Iowa Press, Iowa City.

10. Fehr, W. R., Caviness, C. E., Burmood, D. T., and Pennington, J. S. 1971. Stage of development descriptions for soybeans, Glycine max (L.) Merrill. Crop Sci. 11:929-931.

11. Gergerich, R. C., and Scott, H. A. 1991. Determinants in the specificity of virus transmission by leaf-feeding beetles. Pages 1-13 in: Advances in Disease Vector Research, Volume 8. Springer Verlag, New York.

12. Ghabrial, S. A., Hershman, D. E., and Johnson, D. W. 1990. Distribution of bean pod mottle virus in soybeans in Kentucky. Plant Dis. 74:132-134.

13. Giesler, L. J., Ghabrial, S. A., Hunt, T. E., and Hill, J. H. 2002. Bean pod mottle virus: a threat to U.S. soybean production. Plant Dis. 86:1280-1289.

14. Gu, H., Clark, A. J., de Sa, P. B., Pfeiffer, T. W., and Ghabrial, S. A. 2002. Genetic diver- sity among isolates of Bean pod mottle virus. Phytopathology 92:446-452.

15. Hampton, R., Beczner, L., Hagedorn, D., Bos, L., Inouye, T., Barnett, O., Musil, M., and Meiners, J. 1978. Host reactions of mechanically transmissible legume viruses of the northern temperate zone. Phytopathology 68:989-997.

16. Henn, T. 1989. Analysis of bean leaf beetle feeding behavior in dual-choice preference testing of legumes. M.S. thesis, University of Illinois at Urbana-Champaign.

17. Hibi, T., and Saito, Y. 1985. A dot immunobinding assay for the detection of tobacco mosaic virus in infected tissues. J. Gen. Virol. 66:1191-1194.

18. Hill, J. H. 1999. Soybean mosaic. Pages 7071 in: Compendium of Soybean Diseases. G. L. Hartman, J. B. Sinclair, and J. C. Rupe, eds. American Phytopathological Society Press, St. Paul, MN.

19. Hopkins, J. D., and Mueller, A. J. 1984. Effect of bean pod mottle virus on soybean yield. J. Econ. Entomol. 77:943-947.

20. Horn, N. L., Newsom, L. D., Carver, R. G., and Jensen, R. L. 1970. Effects of virus diseases on soybeans in Louisiana. La. Agric. $13: 12-13,15$

21. Horn, N. L., Newsom, L. D., and Jensen, R. L. 1973. Economic injury thresholds of bean pod mottle and tobacco ringspot virus infection of soybeans. Plant Dis. Rep. 57:811-813.

22. Joplin, C. E. 1974. Pulse crops of the world and their important pests. M.S. thesis, SimonFraser University, Burnaby, British Columbia, Canada.

23. Kogan, M., and Kogan, D. D. 1979. Odontota horni, a hispine leaf miner adapted to soybean feeding in Illinois. Ann. Entomol. Soc. Am. 72:456-461.

24. Kogan, M., Waldbauer, G. P., Boiteau, G., and Eastman, C. E. 1980. Sampling bean leaf beetles on soybean. Pages 201-236 in: Sampling Methods in Soybean Entomology. M. Kogan and D. C. Herzog, eds. Springer Verlag, New York.

25. Krell, R. K. 2002. Bean pod mottle virus ecology and management in Iowa. Ph.D. diss., Iowa State University, Ames.

26. Laemmli, U. K. 1970. Cleavage of structural proteins during the assembly of the head of bacteriophage T4. Nature 227:680-685.

27. Lam, W. F., Pedigo, L. P., and Hinz, P. N. 2001. Population dynamics of bean leaf beetles (Coleoptera: Chrysomelidae) in Central Iowa. Environ. Entomol. 30:562-567.

28. Lin, M. T., and Hill, J. H. 1983. Bean pod mottle virus: occurrence in Nebraska and seed transmission in soybeans. Plant Dis. 67:230233.

29. Lomonossoff, G. P., and Ghabrial, S. A. 2001. Comoviruses. Pages 239-242 in: Encyclopedia of Plant Pathology, Vol. 1. O. Maloy and T. Murray, eds. John Wiley and Sons, New York.

30. McLaughlin, M. R., Barnett, O. W., Gibson, P. B., and Burrows, P. M. 1984. Enzyme-linked immunosorbent assay of viruses infecting forage legumes. Phytopathology 74:965-969.

31. McLaughlin, M. R., Thongmeearkom, P., Goodman, R. M., Milbrath, G. M., Ries, S. M., and Royse, D. J. 1978. Isolation and beetle transmission of cowpea mosaic virus (severe subgroup) from Desmodium canescens and soybeans in Illinois. Plant Dis. Rep. 62:1069-1073.

32. Moore, B. J., Scott, H. A., and Walters, H. J. 1969. Desmodium paniculatum, a perennial host of bean pod mottle virus in nature. Plant Dis. Rep. 53:154-155.

33. Mueller, A. J., and Haddox, A. W. 1980. Observations on seasonal development of bean leaf beetle, Cerotoma trifurcata (Forster) and 
incidence of bean pod mottle virus in Arkansas' soybean. J. Ga. Entomol. Soc. 15:398-403.

34. NASS and USDA. National Agricultural Statistics Service and U.S. Dep. Agric. Crop Prod. 2002 Summary. 2003. CrPr2-1(03).

35. Overall, C. M. 1997. A mircotechnique for dialysis of small volume solutions with quantitative recoveries. Anal. Biochem. 165:208214.

36. Pitre, H. N., Patel, V. C., and Keeling, B. L. 1979. Distribution of bean pod mottle virus on soybeans in Mississippi. Plant Dis. Rep. 63:419-423.

37. Quiniones, S. S., Dunleavy, J. M., and Fisher, J. W. 1971. Performance of three soybean varieties inoculated with soybean mosaic virus and bean pod mottle virus. Crop Sci. 11:662664.

38. Ross, J. P. 1986. Response of early and late planted soybeans to natural infection by bean pod mottle virus. Plant Dis. 70:222-224.

39. Ross, J. P., and Butler, A. K. 1985. Distribution of bean pod mottle virus in soybeans in North Carolina. Plant Dis. 69:101-103.

40. SAS Institute. 1999. User's Manual, version 8.0. SAS Institute, Cary, NC

41. Schwenk, F. W., and Nickell, C. D. 1980. Soybean green stem caused by bean pod mottle virus. Plant Dis. 64:863-865.
42. Scott, H. A., Van Scyoc, J. V., and Van Scyoc, C. E. 1974. Reactions of Glycine spp. to bean pod mottle virus. Plant Dis. Rep. 58:191-192.

43. Skotland, C. B. 1958. Bean pod mottle virus of soybeans. Plant Dis. Rep. 42:1155-1156.

44. Smelser, R. B., and Pedigo, L. P. 1991. Phenology of Cerotoma trifurcata on soybean and alfalfa in central Iowa. Environ. Entomol. 20:514-519.

45. Stace-Smith, R. 1981. Comoviruses. Pages 171-194 in: Handbook of Plant Virus Infections and Comparative Diagnosis. E. Kurstak, ed. Elsevier/North-Holland Biomedical Press, New York.

46. Steinlage, T. A., Hill, J. H., and Nutter, F. W. 2002. Temporal and spatial spread of Soybean mosaic virus (SMV) in soybeans transformed with the coat protein gene of SMV. Phytopathology 92:478-486.

47. Thornberry, H. H. 1966. Plant pests of importance to North American agriculture: Index of plant virus diseases. Agric. Handb. No. 307, U. S. Dep. Agric. Washington, D.C.

48. Towbin, H., Staehelin, T., and Gordon, J. 1979. Electrophoretic transfer of proteins from polyacrlyamide gels to nitrocellulose sheets: procedure and some applications. Proc. Natl. Acad. Sci. USA 76:4350-4354.

49. Tugwell, P., Rouse, E. P., and Thompson, R.
G. 1973. Insects in soybeans and a weed host (Desmodium spp.). Ark. Agric. Exp. Stn. Rep. Ser. No. 214

50. Turner, L. A., and Kogan, M. 1978. Feeding, fecundity, and longevity of teneral bean leaf beetles on different host plants. Proc. North Central Branch Entomol. Soc. Am. 33:35.

51. Waldbauer, G. P., and Kogan, M. 1976. Bean leaf beetle: phenological relationship with soybean in Illinois. Environ. Entomol. 5:35 44

52. Walters, H. J. 1958. A virus disease complex in soybeans in Arkansas. (Abstr.) Phytopathology 48:346.

53. Walters, H. J., and Lee, F. N. 1969. Transmission of bean pod mottle virus from Desmo dium paniculatum to soybean by the bean leaf beetle. Plant Dis. Rep. 53:411.

54. Walters, H. J., Lee, F. N., and Jackson, K. E. 1972. Overwintering of bean pod mottle virus in bean leaf beetles. (Abstr.) Phytopathology 62:808

55. Yang, X. B. 1998. Discolored soybean seeds. Integrated Crop Management IC480(23):173-174. Iowa State University, Ames.

56. Zaumeyer, W. J., and Thomas, H. R. 1948. Pod mottle, a virus disease of beans. J. Agric. Res. 77:81-96. 